\title{
Private Productive Investment in Spain and the United States
}

\author{
Philip Arestis* \\ Ana Rosa González* * \\ Óscar Dejuán***
}

\begin{abstract}
Private productive investment is, or should be, the key variable of any macroeconomic and growth models. Surprisingly enough, after a two-century of long discussions, economists are far from reaching any theoretical agreement, while empirical studies do not confirm or indeed support any particular model. It is true, though, that the most promising results are generally associated with those based on the acceleration principle. In this paper we estimate a model of capital accumulation whose independent variables are: (a) the expected rate of growth of the economy proxied by its past rate; (b) deviations of capacity utilization from its 'normal' level; (c) the long-term real interest rate, i.e. the cost of external finance; (d) deviations between the current profit share and its 'conventional' rate; and (e) deviations of confidence from its 'conventional' level. We examine the empirical evidence in Spain and the USA during the period 1964-2009. Econometric results support our 'flexible accelerator' model of investment.
\end{abstract}

Keywords: Keynesian and Kaleckian macroeconomic models. Fixed capital investment. Accelerator. Capacity utilization.

JEL Classification: E22; B50; C22.

\section{Introduction'}

This paper aims to model and estimate a function which explains the development of private productive investment, i.e. investment in buildings, equipment and vehicles undertaken by companies in order to increase or modernize their productive capacity. Specifically, in this paper we formulate a theoretical model of capital accumulation, whose corner stone is the accelerator principle, which in this particular approach, is introduced by considering the rate of growth of GDP in the previous year. However, our model is not a pure 'accelerator model', since we include several variables, which permit businessmen to deal with the lack of perfect information and the uncertainty, which surrounds the investment decision. These

\footnotetext{
* University of Cambridge, UK, and University of the Basque Country, Spain. E-mail: pa267@cam.ac.uk

** University of Castilla-La Mancha, Spain. E-mail: anarosa.gonzalez@uclm.es

*** University of Castilla-La Mancha, Spain. E-mail: oscar.dejuan@uclm.es

1 This contribution was put together when Ana Rosa González was a visitor at the Department of Land Economy, University of Cambridge, September 2011 to September 2012. It relates to Ana Rosa González's PhD thesis. Ana Rosa González is grateful to Junta de Comunidades de Castilla-La Mancha for their generous financial support.
} 
variables are the following: a) deviations of capacity utilization from its 'normal' level, which collect the short-run adjustments, which permit entrepreneurs to cope with unexpected increases in demand; b) the long-term real interest rate, which accounts for the cost of external resources; c) deviations between the current profit share and its 'conventional' rate, which permit us to consider the distribution of income, which is generated in the productive process and the amount of internal resources available to invest; and d) deviations of confidence from its 'conventional' rate, which are another proxy for expectations about demand. As we discuss in the theoretical part of this paper, the inclusion of the 'conventional' variables, which capture the businessman's expectations about the evolution of the variables in the near future, is perfectly justified in an uncertain context with imperfect information.

In section 2 we review the traditional Keynesian and Kaleckian models based on the accelerator principle. In section 3 we present in detailed our 'flexible accelerator model'. In section 4 we describe the data utilized and test the model against the US and Spanish data from 1964 to 2009. ${ }^{2}$ Section 5 summarizes and concludes.

\section{Models of Investment: The Accelerator Principle}

The cornerstone of the Neoclassical Revolution after 1870 was the marginalist theory of distribution (WALRAS, 1874; MARSHALL, 1890; FISHER, 1930). This theory translates graphically in a downward-sloping demand function for capital. Entrepreneurs are supposed to invest up to the value of the output derived from giving additional machines to the existing number of workers coinciding with the real interest rate they have to endure. After Jorgenson (1963), neoclassical economists usually refer to the rental price or user cost of capital which, in addition to the real interest rate, includes depreciation allowances and taxes. ${ }^{3}$

As a matter of fact, the more recent neoclassical-based models do not worry about the investment function. Investment is supposed to absorb all the savings, which are explained in the process of (individual) utility maximization where the interest rate regulates the allocation of income between actual consumption and future consumption. This Walrasian idea is still alive in the Dynamic Stochastic General Equilibrium (DSGE) models, used by central banks (CLARIDA et al., 1999) and also in the Applied and Computable General Equilibrium (ACGE) models (SCARF; SHOVEN, 1984).

Keynes (1936) tried to show that investment does not depend on savings. In equilibrium both variables coincide, but it is investment, which creates savings through the multiplier mechanism. What does investment depend on? In Keynes

2 In terms of the econometric technique utilised, the Ordinary Least Squares (OLS) has been employed in the estimations throughout.

3 See Baddeley (2003) for a discussion and an econometric exercise on the Jorgenson's (1963) model. 
(op.cit.) two alternative (and probably incoherent) explanations are offered. In Chapter 11 Keynes (op. cit.) refers to the marginal efficiency of capital, where the interest rate continues to be the key determinant of investment, although it is now a monetary phenomenon (determined by the forces of demand and supply of money, instead of being determined in the capital market as a result of the forces of productivity and thrift). In chapter 12 Keynes (1936) highlights the importance of entrepreneurs' long-term expectations (animal spirits), without providing a clearcut explanation of how expectations are formed.

The principle of effective demand and the multiplier were used, a couple of years before Keynes (1936), by the Polish economist Kalecki (1971). Kalecki (1971 refused to accept Keynes' (1936) investment function. In his opinion firms adjust to changes in demand via capacity utilization. When the actual degree of capacity utilization is above the normal level, it then speeds up investment in order to increase capacity.

The different Keynesian strands in the second half of the $20^{\text {th }}$ century can be defined in relation to the investment function. Hicks' ISLM model is based on the marginal efficiency of investment and was a preparation for the first Keynesian-Neoclassical synthesis (HICKS, 1937). The closest disciples of Keynes and his American followers emphasized animal spirits (see, for example, ROBINSON, 1962; MINSKY, 1975). Another group of Post Keynesian economists base their ideas on those of Kalecki, as for example Sawyer (1985) and Lavoie (1992).

The acceleration principle constitutes an approach to investment. The idea is as simple as it is compelling: in order to produce efficiently, entrepreneurs try to keep the desired 'capital/output' ratio, and so they invest whenever they forecast permanent increases in demand. This can be called the 'prospective accelerator'. When expectations of future demand are based on past increases we are using a 'retrospective accelerator', which is the usual procedure in applied studies. The type of accelerator has proved to be superior to other theories of investment on empirical grounds (BADDELEY, 2003). This paper develops and tests a particular model of 'flexible accelerator'. Before presenting it, we deal with the concept further.

The origins of the acceleration principle go back to the early $20^{\text {th }}$ century writings of Carver (1903), Aftalion (1909), Bickerdike (1914) and Clark (1917). Shortly after The General Theory, Harrod (1939) tried to add strength to Keynes' principle of effective demand by joining the multiplier and the accelerator mechanisms. Harrod (op. cit.) discovered that given technology (represented by the desired 'capital/output' ratio $=k)$ and the propensity to save $(s=1-\mathrm{c}$, where $c$ is the propensity to consume), the system exhibits a 'potential' or 'warranted' rate of growth defined as $g_{w}=s / k$. He called it 'the warranted rate' because if the expected rate of growth envisaged by entrepreneurs coincides with $g_{w}$, a macroeconomic equilib- 
rium is warranted. However, we may note that whenever the expected rate was slightly above (or below) $g_{w}$ the economy would accelerate (decelerate) itself until it would explode (or disappear). This unstable pattern became known as the 'knife edge'. Samuelson (1939) adds mathematical precision to show that depending on the values of the parameters the dynamics can be cyclical. After Chenery (1952) economists developed a 'flexible accelerator' model where the adjustment to the optimal capacity occurs step by step. Despite these efforts, the instability of the multiplier-accelerator model deterred most researchers from pursuing it further.

Since the purpose of this paper consists of checking a particular acceleration model of investment, it may be of interest to review other papers with a similar purpose. Epstein and Denny (1983) analyzed investment in the US manufacturing sector during the period 1947-1976. Fazzari and Mott (1986-87) checked empirically Keynesian and Kaleckian theories of investment using the United States manufacturing panel data from the period 1970 to 1980. Acemoglu (1993) applied the accelerator model to the American and British economies with quarterly data from 1965 till 1990. He introduced imperfect information and distinguished between investment accelerator and employment accelerator. Hay and Louri (1995) analyzed UK firms during the years 1960-1985 and found a trade-off between the level of stocks of the company and its investment in capital. Hein and Ochsen (2003) added an interest-rate term to analyze its impact on capital accumulation during the period 1960-1995 in France, Germany, United Kingdom and USA. Surprisingly enough, they found a positive influence of the real interest rate on the rate of accumulation between 1983 and 1995 in the United States. Atesoglu (2004) applied cointegration analysis to the United States data during the period 19472001. Atesoglu (2004) obtained a positive relationship between investment and fiscal as well monetary policy variables, although he found a greater impact for public spending than changes in interest rates. Iyoda (2005) estimated a Japanese investment relationship from 1973 till 2001. His model is based on Davidson and Minsky's ideas about a monetary production economy. Cámara (2008) shows an investment model whose endogenous variables are the rate of capacity utilization and gross profits of the United States firms in the years 1950-2006. Profits turned out to be the only significant variable. Falls and Natke (2007) analyzed the investment of Brazilian firms using panel data. They showed how a Keynesian frame is useful to explain investment development in this country between 1973-1976. Singh $(2008,2009)$ applied cointegration techniques to study the investment effect on the development of economic growth in the years 1950-2001. Singh (2008, 2009) stated the importance of accelerating investment processes. Alexiou (2010) studied the development of investment from 1970 till 2005 for the G7 countries. Alexiou (2010) concluded that profit and capacity utilization are the most relevant explanatory variables in the investment process. 
In the case of the Spanish economy, Andrés et al. (1990), using cointegration, estimated an accelerator model, which included the rate of capacity utilization and the user cost of capital. This analysis covered the period 1964-1986. Espasa and Senra (1993) improved the previous model and reduced its residuals by introducing a new indicator which captures the development of the price of those energetic commodities which are imported. Estrada et al. (1997) estimated a model similar to Andrés et al. (1990) extending the number of observations until 1995. Raymond et al. (1999) estimated an accelerator model, a $q$ model and a cash flow model using Spanish firm data from 1991 to 1997.

The results of econometric models are ambivalent. The good news is that investment models based on the acceleration principle are clearly superior to the alternative ones. The bad news is that one gets a sense of unease when coming across a coefficient of determination $\left(R^{2}\right)$ below 0.5, when Baddeley (2003) and Argitis (2008) showed that $\mathrm{R}^{2}$ could rise dramatically using autoregressive models that explain investment, in the first case, and the accumulation rate, in the second one, in year $t$ by investment and accumulation in year $t-1$ respectively. In Spain, the models with the highest $R^{2}$ are also characterized by including lagged investment among the determinants (ANDRÉS et al., 1990; ESTRADA et al. 1997). Of course, this implies not knowing the true independent variables that influence investment. Applying OLS we estimate a model without including the past level of the accumulation rate as a determinant variable.

\section{An Alternative Post Keynesian Accelerator Model Accounting for Changes in Capacity Utilization and Interest Rates}

In this paper we propose a theoretical explanation of the accumulation pace, which contains as the key determinant of investment the expected growth of autonomous demand that can be proxied by recent increases in aggregate demand. This is nothing other than the acceleration mechanism that relies on an optimal 'capital/output' ratio, corresponding to the 'normal' degree of capacity utilization. The accumulation rate, $g_{t}$, which is the dependent variable in our regression, is proxied by the rate of growth of investment, as it is presented in equation (1):

$$
g_{t}=\frac{I_{t}-I_{t-1}}{I_{t-1}}
$$

Its main determinant will be the rate of growth of gross domestic output, $y_{t}$, which is calculated as describe in expression (2): 


$$
y_{t}=\frac{G D P_{t}-G D P_{t-1}}{G D P_{t-1}}
$$

In a market economy, errors of prediction about the evolution of demand result in overutilization or underutilization of capacity. In the case of overutilization entrepreneurs will speed up investment, over and above the level derived from the strict application of the acceleration principle. Firms will rush to build capacity in order to attend efficiently the new increases in demand and to make up for the past gaps. If entrepreneurs face underutilization of capacity they will slow down the investment decisions demanded by the strict acceleration principle.

The degree of capacity utilization may be defined by the ratio between the number of hours per day firms use the installed capacity, $h_{t}$, and the number of hours they consider optimal at the moment of investment: $u=h / h^{*}$. The definition of the 'normal', 'desired' or 'optimal' degree of capacity utilization continues to be a source of controversy (KURZ, 1986; LAVOIE et al., 2004). Mixing Sraffian and Kaleckian arguments we define it as the rate that maximizes the rate of profit (adjusted for risk). The actual profit rate could grow a little by enlarging the working day several hours. But this behaviour may cause a loss of customers if there is a peak in demand that firms are not ready to attend to, immediately.

Figure 1 summarizes the argument. The maximum degree of capacity utilization is set at $u_{M}$. The maximum absolute rate of profit associated to it is $M x-r$. The optimal rate is fixed at $u^{*}$. This conveys the maximum rate of profit in the economic sense, i.e. free of the risk of loosing customers $\left(M x-r^{*}\right)$. Point $u_{m}$ stands for the so called 'minimum of exploitation'; below it, firms do not cover variable costs, so they would have to shut down.

Nowadays most national agencies conduct a survey asking entrepreneurs about their operating capacity rate. Even in boom periods they say they operate between 80 and $85 \%$ of the installed capacity. This indicates that they associate 'full capacity' ( $u=1$ or $100 \%$ ) to our point Mx-r. What actually matters in our model, however, is the deviation of the effective rate of utilization from the 'normal' one which we can formalize as follows:

$$
u_{t}^{d}=\frac{u_{t}-u^{*}}{u^{*}}
$$


Figure 1 - Degree of capacity utilization

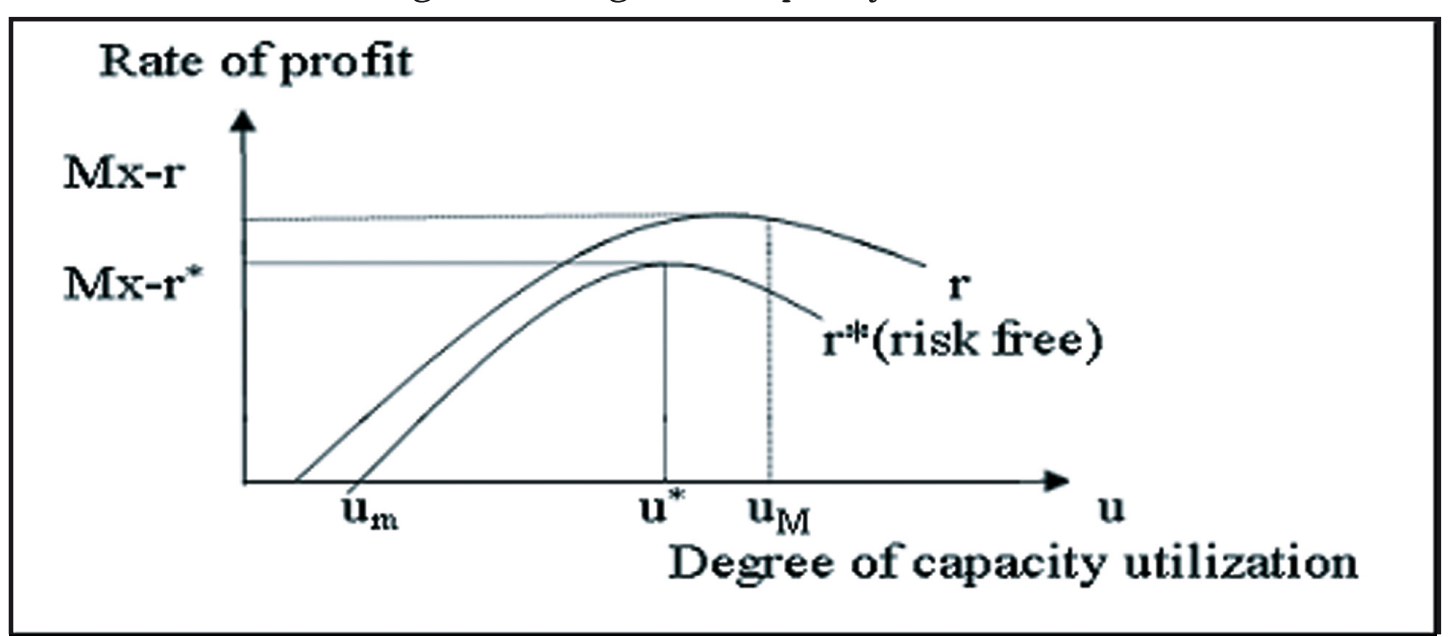

Source: Lavoie (1992).

What about financial conditions? As we have seen, most investment models consider the real interest rate as the main determinant of investment, if not the only one. The empirical evidence plainly refutes this claim. At the end of boom periods, investment rockets despite high interest rates. At the beginning of a recession, investment falls dramatically despite low (even nil) real interest rates. ${ }^{4}$ Of course this does not mean that investment is positively related to the interest rate; it only means that the main determinants lie somewhere else. However, since in the real world it is not possible to finance new investment projects by using only internal resources, the current real long-term interest rate $\left(i_{t}\right)$ is utilized as a proxy of the cost of external finance.

Following Keynes (1936) the 'conventional' level of a variable is the value that has been prominent in the recent past and entrepreneurs expect to prevail in the near future. The 'conventional' rate exhibits hysteresis in the sense that once people get accustomed to the new rate (higher or lower), it then becomes the reference for investment decisions.

Financial conditions involve many other issues, such as degree of indebtedness and leverage of firms; liquidity problems and so on. All of them have been included into the independent term, which also account for the 'state of confidence of entrepreneurs', and for 'modernization investment', i.e. the part of investment that does not try to increase capacity but to change it in order to produce different goods or the same goods with different methods.

Post Keynesianism also gives a key role to profitability following Kalecki's writings. ${ }^{5}$ The impact of this variable cannot be ignored, since profit shares reflect

$4 \quad$ Kalecki (1933) introduces the principle of increasing risk, which points to a negative relationship between debt service and investment.

$5 \quad$ Kalecki (1933) considers expected profitability and interest rates as key explanatory elements of the investment decision. Neverthless, Kalecki (1968) modifies his first contribution by determining investment as a function of cash flows, technical progress and profitability. 
the conflict between workers and capitalists in order to distribute the income generated in the productive process. ${ }^{6}$ As a consequence, the profit share is supposed to be a financial constraint in the sense that it determines the amount of internal resources, which are available to invest. Apart from that, there is another case, which has been recognized by the majority of the schools of economic thought, i.e. theoretically investment will take place following the highest value of the rate of profit until the point when this rate is homogeneous between the different sectors of the economy and the expectations of obtaining additional profits over the normal rate (by considering normal prices and normal rates of capacity utilization) disappear. ${ }^{7}$ Our model accounts for this element by including the deviation between the effective profit share $(\pi)$ and its conventional level $\left(\pi^{*}\right)$, which is built as follows:

$$
\pi_{t}^{d}=\frac{\pi_{t}-\pi^{*}}{\pi^{*}}
$$

In order to highlight the role of expectations in our model we introduce an economic indicator, which reflects consumer opinions about the development of the goods market in the near future. This is an alternative way to approach expected demand. Using this index we built another deviation $\left(c^{d}\right)$, similar to the previous case, as formula (6) displays:

$$
c_{t}^{d}=\frac{c_{t}-c^{*}}{c^{*}}
$$

where $c_{t}$ capture the current state of consumer expectations and $c *$ accounts for the conventional value of this variable.

In this model, except for the rate of growth of production, which is also a proxy of expected demand, all the variables are built including 'conventions' . ${ }^{8}$ Following Keynes (1936) these elements are basic when businessmen decide to invest

$6 \quad$ Bhaduri and Marglin (1990) consider the current rate of profit as the most important explanatory variable in the accumulation pace.

7 See Dutt (2011) for a discussion of the profit-led growth regime.

8 The 'normal' and 'conventional' values are calculated as the average value of the variable during the period for some explanatory elements. Specifically, we can use this method in the case of the profit shares since this variable does not exhibit deep fluctuations through time. In the case of the confidence indicator, the period analysed is short, and an average value can be used as representative of the period. However, the 'normal' capacity utilization rate is proxied by the rate of capacity utilization of the previous period, since this variable is much more volatile than the previous elements. As a result expectations about this variable, which permits adjustment in the short-run, have to change faster. 
in an uncertainty world where the information is not complete and mathematics is not the perfect tool to take decisions.

We are ready to formulate the equation to be estimated. The general form of the model makes the accumulation rate $\left(g_{t}\right)$ a function of the rate of growth of output $\left(y_{t}\right)$, the deviation of capacity utilization from its 'normal' level $\left(u_{t}^{d}\right)$, the rate of interest $\left(i_{t}\right)$, the deviation between the current profit share and its 'conventional' rate $\left(\pi^{d}\right)$ and the deviation of the confidence indicator from its 'conventional' level $\left(c^{d}\right)$, as it is presented in equation (6):

$$
\begin{gathered}
g_{t}=f\left(y_{t}, u_{t}^{d}, i_{t}, \pi_{t}^{d}, c_{t}^{d}\right) \\
++-++
\end{gathered}
$$

where the variables have the meanings assigned to them above and the sign below a variable is denoting the partial derivative with respect to that variable.

\section{Empirical Analysis}

\subsection{Data and Econometric Technique Utilised}

In spite of the importance of investment in economic development, investment has not considered exhaustively in the Spanish economic literature. Specifically, the most relevant studies date from the 1990s (ANDRÉS et al., 1990; ESPASA; SENRA, 1993; ESTRADA et al., 1997). So, it is refreshing to take on board and apply Post Keynesian ideas about the determinants of investment. Apart from this, it is necessary to compare the Spanish structure with another largest and most dynamic economy; we have, therefore, chosen to do so in relation to the United States.

The data for the analysis of the productive investment of the Spanish firms come from the Instituto Valenciano de Investigaciones Económicas (IVIE), Instituto Nacional de Estadística (INE), Ministry of Industry, Trade and Tourism, Eurostat and the Organization for Economic Co-operation and Development (OECD). For the USA we rely on data provided by the Bureau of Economic Analysis (BEA), the Federal Reserve (FED) and the OECD. Although in the US case it is possible to find the necessary time series data of the variables, which have been used in this analysis before 1964, the availability of the Spanish business investment only spans from 1964 till 2007. We also isolate another period of analysis, 1994-2007. The reason, which justifies it, is the inclusion of a new variable, which reflects confidence and expectations about the development of the markets. In the Spanish case, this kind of information is only available since 1994. These aspects impose the time limit of the period used for estimation. ${ }^{9}$

9 We try to use the same estimation period for both Spain and the US for comparative purposes.

ARESTIS, P.; GONZÁLEZ, A. R.; DEJUÁN, O. Private Productive Investment in Spain... 
In this paper, the models were estimated using the Ordinary Least Squares (OLS) technique due to these series being stationary. ${ }^{10}$ In both time periods (19642007, 1994-2007) we check for the stationarity of the data after applying the augmented Dickey-Fuller (ADF) tests, the Phillips-Perron (PP) tests, the GLS-based Dickey-Fuller (DF-GLS) tests, the Elliot-Rothenberg-Stock point optimal (ERS) tests and the Kwiatkowski-Phillips-Schmidt-Shin (KPSS) tests. ${ }^{11}$ The null hypothesis for all these tests is the presence of a unit root, except in the KPSS tests where we find the null hypothesis of stationarity.

In order to check for structural changes we apply the squared cumulative sum (CUSUM) test, which shows us the stability of the model. ${ }^{12}$

EViews version 5 is the software package, which has been used to estimate the models and conduct the statistic tests.

\subsection{Empirical Analysis of Investment in Spain (1964-2009)}

During the period 1964-2009 the Spanish economy experienced numerous and deep changes in several levels: transition to a new political system, openness of the economy, liberalization and deregulation of the banking system, modernization of the institutions, implementation of modern legislation, etc... All these new changes have configured a new environment in which the businessmen have to take the investment decision. However, there is a fundamental fact in the development of the mentioned changes, which is that the Spanish economy joined the European Union in 1986. We may notice that the sub-period 1964-86 coincides with the sample analyzed by Andrés et al. (1990). To the best of our knowledge, the period 1987-2007 has not been analyzed yet; even under such circumstances when it becomes necessary to study the behaviour of this key macroeconomic variable through time, and especially, in a new context that is more competitive and global like the one that emerged after the changes discussed above.

In order to avoid spurious regressions, it is mandatory to check the stationarity of the time series under consideration. As it is shown in Tables V and VI (Appendix), we can accept the stationarity of the data where we test our theoretical proposition. Tables I reports the coefficients of the regression, which has been estimated for the period 1964-2009 by means of the OLS technique.

10 See Pulido and Pérez (2001) for an explanation of the OLS method under the circumstances as in the current paper.

11 See Dickey and Fuller (1979, 1981), Nelson and Plosser (1982), Phillips and Perron (1988), Kwiatkowski (1992) and Elliott et al. (1996).

12 See Brown et al. (1975) for details of the CUSUM test. As it can be seen from Figures 1 and 2 (Appendix), the CUSUM tests suggest that the parameters of the estimated relationships are stable over time. 


\begin{tabular}{ccc}
\multicolumn{3}{c}{$g_{t}=\beta_{0}+\beta_{1} y_{t-1}+\beta_{2} u_{t-1}^{d}+\varepsilon_{t}$} \\
\hline & Coefficient & t-Statistic [p-value] \\
\hline $\boldsymbol{\beta}_{\mathbf{0}}$ & 0.002644 & $0.130085[0.8971]$ \\
$\boldsymbol{\beta}_{\mathbf{1}}$ & 1.330638 & $2.685121[0.0104]$ \\
$\boldsymbol{\beta}_{\mathbf{2}}$ & 0.831426 & $2.054898[0.0463]$ \\
\hline R-squared & 0.3141828 & \\
\hline
\end{tabular}

Source: Developed by the authors.

The explanation of the accumulation pace in Spain from 1964 till 2009 is the straight application of the 'flexible accelerator' model of investment (CHENERY, 1952). Specifically, the parameters displayed in Table I show how investment is fuelled mainly by expectations about future demand, which are proxied by the rate of growth of GDP in t-1 (1.330638). Moreover, Model I also highlights a positive influence, which arises from the deviation of capacity utilization lagged one period (0.831426). Both variables have the expected sign on theoretical grounds. The goodness of fit is reasonable $\left(\mathrm{R}^{2}=0.31\right)$, especially when it is recalled that our model does not include a lag of the dependent variable as one of the explanatory elements. In order to confirm the validity of these econometric results we applied the tests discussed above, which are presented in Table VI (Appendix). All these tests permit us to state that our model satisfied the basic hypotheses of the linear regression model (GUJARATI, 1997), i.e. there is no autocorrelation of first-, secondand third-order; the residuals of the model are normally distributed and they also exhibit no conditional heteroscedasticity (ARCH effects). ${ }^{13}$ The two versions of the White tests which are applied conclude on the homocedasticity of the model.

As we have argued, in the second stage of the analysis we added a new variable, the deviation of the consumer confidence indicator, and estimated the model from 1994 till 2009. Table II exhibits the results.

Table 2 - Model II (Spain 1994-2009)

\begin{tabular}{|c|c|c|}
\hline & Coefficient & t-Statistic [p-value] \\
\hline Bo & -0.02567 & $-0.729336[0.4843]$ \\
\hline$\beta_{1}$ & 2.504216 & $2.607059[0.0284]$ \\
\hline$\beta 2$ & 1.285907 & $4.759417[0.0001]$ \\
\hline$\beta 5$ & 0.023209 & $1.972443[0.0800]$ \\
\hline R-squared & 0.868699 & \\
\hline
\end{tabular}

13 See Engle (1982) for a discussion of ARCH models.

ARESTIS, P.; GONZÁLEZ, A. R.; DEJUÁN, O. Private Productive Investment in Spain... 
Model II emphasizes the role of the rate of growth of GDP lagged by one period, which is again the key element in the accumulation process (2.504216). There are also two deviations, whose impact is positive, although this effect is much lower than the in the previous case. Specifically, these influences arise from deviations of the rate of capacity utilization in the current period (1.285907) and deviations of the confidence indicator from its 'conventional' level in $t-3$ (0.023209). This regression permits us to explain $87 \%$ of the variations in the business accumulation rate, which took place from 1994 till 2009. The acceptance of these econometric results is supported by the statistics provided in Table VII (Appendix). ${ }^{14}$

As a general comment, the results presented in this section suggest that the corner stone of the accumulation process in the business sector are the expectations of future demand, as it was advanced in the theoretical part of this paper. Our testable hypothesis also points to a positive and remarkable impact of capacity utilization on investment, which has been corroborated by Models I and II. The influence of financial elements is not significant, since their impact is superseded by the power of expectations, especially expectations about demand (which are introduced in our model by the accelerator term and confidence indicator). Finally, it is important to note that for the Spanish economy the distributive variable (deviation of profit shares from its 'conventional' level) does not exert any influence.

\subsection{An Empirical Analysis of Investment in the United States (1964-2007)}

Before testing our theoretical formulation we apply several unit root and stationarity tests, whose results of the unit root tests are shown in Tables VI and VII (Appendix). The presence of unit roots in the data is rejected in both the United States time series and in the Spanish case. We also apply OLS to estimate the function for the the United States. Table 3 shows the results of the estimated relationship for the US economy.

Table 3 - Model III (the United States 1964-2009)

\begin{tabular}{|c|c|c|}
\hline \multicolumn{3}{|c|}{$g_{t}=\beta_{0}+\beta_{1} y_{t-1}+\beta_{2} u_{t}^{d}+\beta_{3} i_{t-2}+\varepsilon_{t}$} \\
\hline & Coefficient & t-Statistic [p-value] \\
\hline$\beta_{0}$ & 0.01045 & $0.807950[0.4239]$ \\
\hline$\beta_{1}$ & 1.451272 & $4.311815[0.0001]$ \\
\hline $\boldsymbol{\beta}_{2}$ & 1.140988 & $7.051653[0.0000]$ \\
\hline$\beta_{3}$ & -0.554612 & $-1.914089[0.0628]$ \\
\hline R-squared & 0.668437 & \\
\hline
\end{tabular}

Source: Developed by the authors.

14 See also Figure 2, which proves the stability of the estimated parameters in Models I and II over the period of investigation. 
In the case of the US the accumulation pace during the period 1964-2007 is explained by the impact of the rate of growth in $t-1$ (1.451272), current deviations of the rate of capacity utilization from its 'normal' level (1.140988), and the rate of interest lagged two periods (-0.554612). Although the first two variables exert a positive effect on accumulation the impact of the accelerator is higher. However, the distributive variable, i.e. deviations of profit shares, has no impact on investment decisions. The presence of the impact of capacity utilization on accumulation is in clear contrast to Argitis's (2008) results, which demonstrated the absence of any impact of capacity utilization on the US business investment. Model IV can explain the $67 \%$ of the changes in accumulation which happened since $1964 .{ }^{15}$

Table 4 presents the parameters of the model which analyses the development of accumulation since 1994.

Table 4 - Model IV (the United States 1994-2009)

\begin{tabular}{ccc}
\multicolumn{3}{c}{$g_{t}=\beta_{0}+\beta_{1} y_{t-1}+\beta_{2} u_{t-1}^{d}+\varepsilon_{t}$} \\
\hline & Coefficient & t-Statistic [p-value] \\
\hline $\boldsymbol{\beta 0}$ & -0.057076 & $-1.454734[0.1695]$ \\
$\boldsymbol{\beta} \mathbf{1}$ & 3.062412 & $2.526896[0.0253]$ \\
$\boldsymbol{\beta 2}$ & 1.506985 & $2.500304[0.0266]$ \\
\hline R-squared & 0.68055 & \\
\hline
\end{tabular}

Source: Developed by the authors.

The study of business investment over the period 1994-2009 points to two variables as significant elements, which can exert a positive influence on accumulation: a) the deviation of the rate of capacity utilization from its 'normal' level lagged one period (1.506985); and b) changes in production of the previous year (3.062412). Model IV shows a coefficient of determination close to 69\%. As usual, the key influence emanates from the accelerator term. We may note that in this shorter period the cost of financial resources is not significant, while if we enlarge the period under consideration its impact is stronger. For this particular economy, expectations about confidence and deviations of the profit shares have not any kind of effect on the investment decision independently of the time horizon considered.

\section{Summary and Conclusions}

We have tested a Post Keynesian model of capital accumulation. Our empirical results show that accumulation accelerates when the rate of growth of GDP

15 The constancy of the coefficients in models III and IV is checked by means of the CUSUM test, as it is shown in Figure 2 for Spain and Figure 3 for the United States. 
speeds up. Our accelerator model is flexible enough to include several positive impacts, which come from the deviation of capacity utilization over its normal level, the deviation between the current profit share and its conventional level and the deviation of the confidence indicator over its conventional level. The model also takes into account the negative impact of the cost that emanates from the banking sector, which compels businessmen to postpone their projects until they find more affordable resources. Applying OLS we are able to conclude that the rate of growth of demand (i.e. the accelerator mechanism) is always the key explanatory variable of investment, while the influence of the four ancillary variables (real interest rates, deviations of capacity utilization, of profit share and confidence) has been significant in some periods only.

The comparison between the US and the Spanish results shows how the 'flexible accelerator' model captures the essential explanatory variables of the investment decision in the business sector as noted above. However, the impact of the rest of the variables varies through time and in both countries. An element whose impact is not homogeneous is the deviation of the confidence indicator, which is a determinant of accumulation in Spain since 1994 but not in the United States. Regarding the deviations of financial elements, the regressions only find an impact in the case of the United States, although they are less important than those effects, which emanate from expectations about demand or capacity utilization. The econometric results produced for the purposes of this study support the theoretical propositions as postulated therein.

\section{References}

ACEMOGLU, D. Learning About Other's Actions and the Investment Accelerator. The Economic Journal, Cambridge, US, v. 10, n. 417, p. 318-328, Mar. 1993.

ALEXIOU, C. A Keynesian-Kaleckian model of investment determination: a panel data investigation. Journal of Post Keynesian Economics, Armonk, US, v. 32, n. 3, p. 427-444, Spring 2010.

AFTALION, A. La Réalité des surproductions générales: Essai d'une théorie des crises générales et périodiques. Paris: L. Larose $\mathcal{E}$ L. Tenin, 1909.

ANDRÉS, J. et al. La Inversión en España: Econometría con Restricciones de Equilibrio. Barcelona: A. Bosch, 1990.

ARGITIS, G. Finance, Investment and Macroeconomic Performance. European Research Studies, v. 11, n. 1-2, p. 71-87, 2008.

ATESOGLU, H. S. Defense Spending and the Investment in the United States. Journal of Post Keynesian Economics, Armonk, US, v. 27, n. 1, p. 163-169, Fall 2004.

BADDELEY, M. Investment: Theories and Analysis. Basingstoke: Palgrave Macmillan, 2003. 
BHADURI, A.; MARGLIN, S. Unemployment and the real wage: the economic basis for contesting political ideologies. Cambridge Journal of Economics, London, UK, v. 14, n. 4, p. 375393, 1990.

BICKERDIKE, C. F. A Non-Monetary Cause of Fluctuations in Employment. Economic Journal, Cambridge, US, v. 24, n. 95, p. 357-370, Sep. 1914.

BROWN, R.H.; DURBIN, J.; EVANS, J. M. Techniques for testing the constancy of regression relationships over time. Journal of the Royal Statistical Society, London, UK, v. 37, n. 2, p. 149-163, 1975.

CÁMARA, S. Determinantes Reales y Financieros de la Inversión en Estados Unidos. Análisis Teórico y Estimación Empírica. In: JORNADAS DE ECONOMÍA CRÍTICA, 11., 2008, Bilbao. Anales... Bilbao: Asociación de Economía Crítica, 2008.

CARVER, T. N. The Relation of Abstinence to Interest. Quarterly Journal of Economics, Cambridge, US, v. 18, n. 1, p. 142-145, Nov. 1903.

CHENERY, H. B. Overcapacity and the Acceleration Principle. Econometrica, Chicago, US, v. 20, n. 1, p. 1-28, Jan. 1952.

CLARIDA, R.; GALÍ, J.; GERTLER, M. The Science of Monetary Policy: A New Keynesian Perspective. Journal of Economic Literature, Nashville, US, v. 37, n. 4, p. 1661-1707, Dec. 1999.

CLARK, J. M. Business Acceleration and the Law of Demand. Journal of Political Economy, Chicago, US, v. 25, n. 3, p. 217-235, Mar. 1917.

DICKEY, D. A.; FULLER, W. A. Distribution of the Estimator for Autoregressive Time Series with a Unit Root. Journal of the American Statistical Association, New York, US, v. 74, n. 366, p. 427-431, Jun. 1979.

Likelihood Ratio Statistics for Autoregresssive Time Series with a Unit Root. Econometrica, Chicago, US, v. 49, n. 4, p. 1057-1072, Jul. 1981.

DUTT, A. K. Growth and income distribution: a Post Keynesian perspective. In: HEIN, E.; STOCKHAMMER, E. (Ed.). A Modern Guide to Keynesian Macroeconomics and Economic Policies. Cheltenham: Edward Elgar, 2011.

ELLIOTT, G.; ROTHENBERG, T.J.; STOCK, J. H. Efficient Tests for an Autoregressive Unit. Econometrica, Chicago, US, v. 64, n. 4, p. 813-836, Jul. 1996.

ENGLE, R. F. Autoregressive Conditional Heteroscedasticity with Estimates of Variance of United Kingdom Inflation. Econometrica, Chicago, US, v. 50, n. 4, p. 987-1008, Jul. 1982.

ESPASA, A.; SENRA, E. Consideraciones sobre la función de inversión en España. Working Paper, 1993.

EPSTEIN, L. G.; DENNY, M. G. S. The multivariate flexible accelerator model: Its empirical restrictions and an application to U. S. manufacturing. Econometrica, Chicago, US, v. 51, n. 3, p. 647-674, May 1983.

ESTRADA, A. et al. La inversión en España, Madrid: Banco de España, Servicio de Estudios Económicos, 1997.

FAZZARI, S. M.; MOTT, T. L. The Investment Theories of Kalecki and Keynes: An Empirical Study of Firm Data, 1970-1982. Journal of Post Keynesian Economics, Armonk, US, v. 9, n. 2 , p. 171-187, Winter 1986-87. 
FALLS, G. A.; NATKE, P. A. An Empirical Analysis of a Keynesian Investment Theory Using Brazilian Firm-level Panel Data. Journal of Post Keynesian Economics, Armonk, US, v. 29, n . 2, p. 501-519, Spring 2007.

FISHER, I. The Theory of Interest. New York: Macmillan, 1930.

GINSBURGH, W.; KEYZER, M. The Structure of Applied General Equilibrium Models. Cambridge, US: The MIT, 2002.

GUJARATI, D. Econometría Básica. Bogotá: McGraw-Hill Interamericana, 1997.

HARROD, R. F. An essay in dynamic theory. Economic Journal, Cambridge, US, v. 49, n. 139, p.14-33, Mar. 1939.

HAY, D.; LOURI, H. An Empirical Note on the Investment Behaviour of U. K. Firms, 1960-85. Journal of Post Keynesian Economics, Armonk, US, v. 17, n. 4, p. 579-591, Summer 1995.

HEIN, E.; OCHSEN, C. Regimes of Interest Rates, Income Shares, Savings and Investment: a Kaleckian Model and Empirical Estimations for Some Advanced OECD Economies. Metroeconomica, Oxford, GB, v. 54, n. 4, p. 404-433, Nov. 2003.

HICKS, J. Mr Keynes and the "classics": a suggested interpretation. Econometrica, Chicago, US, v. 5, n. 2, p.147-159, Apr. 1937.

IYODA, M. The Determination of Investment in the Monetary Production economy: a Theory and its Empirical Application in the Post Keynesian Tradition. Journal of Post Keynesian Economics, Armonk, US, v. 28, n. 1, p. 115-133, Fall 2005.

JORGENSON, D. W. Capital theory and investment behaviour. American Economic Review, Nashville, US, v. 53, n. 2, p. 247-59, 1963.

KALECKI, M. Selected Essays on the Dynamics of the Capitalist Economy 1933-1970. Cambridge: Cambridge University Press, 1971.

KEYNES, J. M. The General Theory of Employment, Interest and Money. London: Macmillan, 1936.

KWIATKOWSKI, D. et al. Testing the null hypothesis of stationarity against the alternative of a unit root: How sure are we that economic time series have a unit root? Journal of Econometrics, Amsterdam, NL, v. 54, p. 159-178, 1992.

KURZ, H. Normal positions and capacity utilization. Political Economy: Studies in the Surplus Approach, Torino, IT, v. 2, n. 1, p. 37-54, 1986.

LAVOIE, M. Foundations of Post Keynesian Economic Analysis. Aldershot, UK: Edward Elgar, 1992. Introduction to Post Keynesian Economics. New York: Palgrave: Macmillan, 2006.

LAVOIE, M.; RODRÍGUEZ, G.; SECCARECCIA, M. Similitudes and Discrepancies in Post Keynesian and Marxist Theories of Investment: A Theoretical and Empirical Investigation. International Review of Applied Economics, Kent, GB, v. 18, n. 2, p. 127-149, 2004.

MARSHALL, A. Principles of Economics. London: Macmillan, 1890.

MINSKY, H. John Maynard Keynes. New York: Columbia U.P., 1975.

NELSON, C.R.; PLOSSER, C. Trends and Random Walks in Macroeconmic Time Series: Some Evidence and Implications. Journal of Monetary Economics, Amsterdam, NL, v. 10, n. 2, p. 139-162, 1982. 
PHILLIPS, P.C.B.; PERRON, P. Testing for a Unit Root in Time Series Regression. Biometrika, London, UK, v. 75, n. 2, p. 335-346, 1988.

PULIDO, A.; PÉREZ, J. Modelos Econométricos. Madrid: Pirámide, 2001.

RAYMOND, J. L.; MAROTO, J. A.; MELLE, M. Inversión y crecimiento empresarial: Factores condicionantes. Papeles de Economía Española, La Rioja, v. 78-79, p. 102-121, 1999.

ROBINSON, J. V. Essays on the Theory of Economic Growth. London: Macmillan, 1962.

SAMUELSON, P. Interaction between the multiplier analysis and the principle of acceleration. Review of Economic Statistics, Cambridge, US, v. 21, n. 2, p. 75-78, May 1939.

SAWYER, M. The Economics of Michal Kalecki. London: Macmillan, 1985.

SCARF, H.; SHOVEN, J. B. Applied General Equilibrium Analysis. Cambridge: Cambridge University Press, 1984.

SERRANO, F. Long Period Effective Demand and the Sraffian Supermultiplier. Contributions to Political Economy, Oxford, UK, v. 14, p. 67-90, 1995.

SINGH, T. Testing the Neoclassical Long-run and the Keynesian Short-run Effects of Investment on Output and Growth in India. Journal of Post Keynesian Economics, Armonk, US, v. 31, n. 2, p. 271-297, Winter 2008.

TREZZINI, A. Capacity Utilisation in the Long Run and the Autonomous Components of Aggregate Demand. Contributions to Political Economy, Oxford, UK, v. 14, p. 33-66, 1995.

. Capacity Utilisation in the Long Run: Some Further Considerations. Contributions to Political Economy, Oxford, UK, v. 17, p. 53-67, 1998.

WALRAS, L. Elements d'économie politique pure, ou théorie de la richesse sociale. Paris: Corbaz, 1874. 


\section{Appendix}

Table 5 - Unit root tests (1964-2009)

\begin{tabular}{cccccc}
\hline & $\mathbf{g}$ & $\mathbf{y}$ & $\mathbf{u}^{\mathbf{d}}$ & $\mathbf{i}$ & $\boldsymbol{\pi}^{\mathbf{d}}$ \\
\hline SPAIN & & & & \\
\hline ADF & $-3.875^{*}(0)$ & $-1.782^{* * *}(0)$ & $-5.651^{*}(1)$ & $-1.929^{* * *}(0)$ & $-2.919^{*}(1)$ \\
PP & $-3.636^{*}$ & $-1.671^{* * *}$ & $-4.089^{*}$ & $-1.972^{* *}$ & $-3.026^{*}$ \\
DFGLS & $-3.317^{*}(0)$ & $-1.875^{* * *}(0)$ & $-4.689^{*}(0)$ & $-2.294^{* *}(0)$ & $-1.795(1)$ \\
ERS & $3.803^{* * *}(0)$ & $5.652(0)$ & $0.818^{*}(1)$ & $2.871^{* *}(0)$ & $18.924(1)$ \\
KPSS & 0.137 & 0.114 & 0.139 & 0.17 & 0.327 \\
\hline UNITED STATES & & & & \\
\hline ADF & $-5.076^{*}(1)$ & $-4.266^{*}(0)$ & $-6.056^{*}(1)$ & $-1.532(0)$ & $-4.404^{*}(1)$ \\
PP & $-3.376^{* *}$ & $-3.796^{*}$ & $-4.487^{*}$ & $-1.644^{* * *}$ & -1.313 \\
DFGLS & $-3.699^{* *}(0)$ & $-3.786^{*}(0)$ & $-4.445^{*}(0)$ & $-3.012^{*}(1)$ & $-2.203(0)$ \\
ERS & $2.475^{*}(1)$ & $3.384^{* * *}(0)$ & $1.044^{*}(1)$ & $1.289^{*}(1)$ & $4.897^{* *}(3)$ \\
KPSS & 0.089 & 0.099 & 0.305 & 0.175 & 0.115 \\
\hline
\end{tabular}

Note: $*{ }^{* *}$ and $* * *$ indicate the statistical significance and the rejection of the null at the 1 , 5 and 10 percent levels, respectively. 


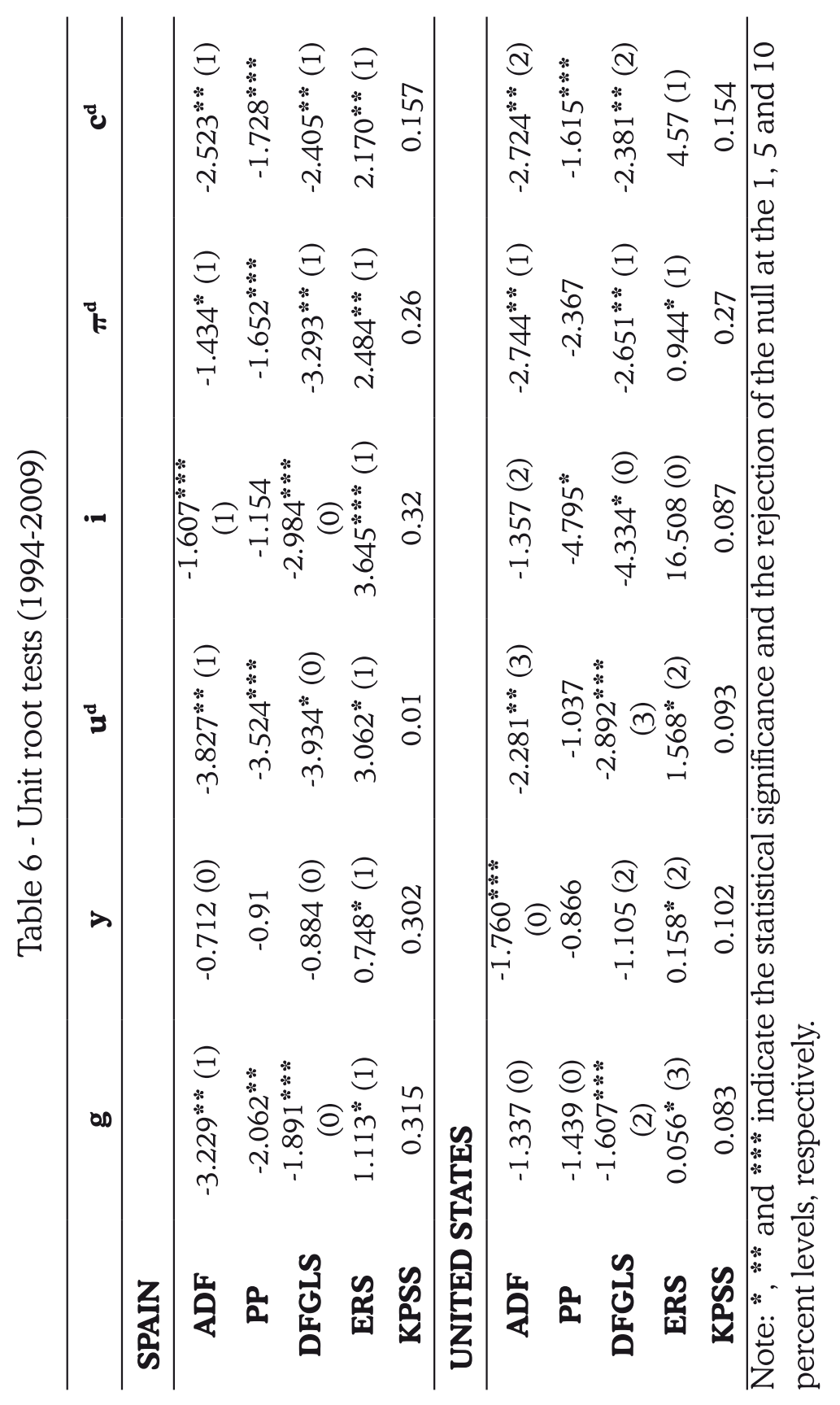


Table 7 - Diagnostic statistics

Statistic tests

\begin{tabular}{|c|c|c|}
\hline SPAIN & 1964-2009 & 1994-2009 \\
\hline LM (1) & $0.186621[0.6681]$ & 0.011308 [0.9179] \\
\hline LM (2) & $0.591963[0.5581]$ & $1.147986[0.3705]$ \\
\hline LM (3) & $0.394556[0.7576]$ & $1.444760[0.3202]$ \\
\hline White & $1.725288[0.1640]$ & $0.491862[0.7955]$ \\
\hline White X & $7.961520[0.1584]$ & $0.651075[0.7288]$ \\
\hline ARCH (1) & $3.740115[0.0601]$ & $0.653468[0.4379]$ \\
\hline ARCH (2) & $2.199847[0.1244]$ & $0.344230[0.7188]$ \\
\hline Jarque-Bera & $1.493643[0.4739]$ & $2.940760[0.2300]$ \\
\hline AIC & -2.507164 & -3.970117 \\
\hline SC & -2.385514 & -3.796286 \\
\hline D-W & 1.782524 & 1.866099 \\
\hline USA & 1964-2009 & 1994-2009 \\
\hline LM (1) & $2.349582[0.1334]$ & $0.180654[0.6783]$ \\
\hline LM (2) & $1.165908[0.3225]$ & $0.214022[0.8106]$ \\
\hline LM (3) & $0.786247[0.5093]$ & $0.131178[0.9393]$ \\
\hline White & $1.27072[0.2944]$ & $0.494624[0.7402]$ \\
\hline White X & $1.073212[0.4068]$ & $0.75383[0.6022]$ \\
\hline ARCH (1) & $2.431493[0.1266]$ & $0.166962[0.6895]$ \\
\hline ARCH (2) & $2.50864[0.0944]$ & $0.459451[0.6432]$ \\
\hline Jarque-Bera & $0.598773[0.7413]$ & $2.901746[0.2344]$ \\
\hline AIC & -3.390238 & -2.870375 \\
\hline SC & -3.228039 & -2.725515 \\
\hline D-W & 1.463168 & 1.989922 \\
\hline
\end{tabular}

Note: The values in parenthesis indicate the p-value of each test. 
Figure 2 - Cusum Test for Spain

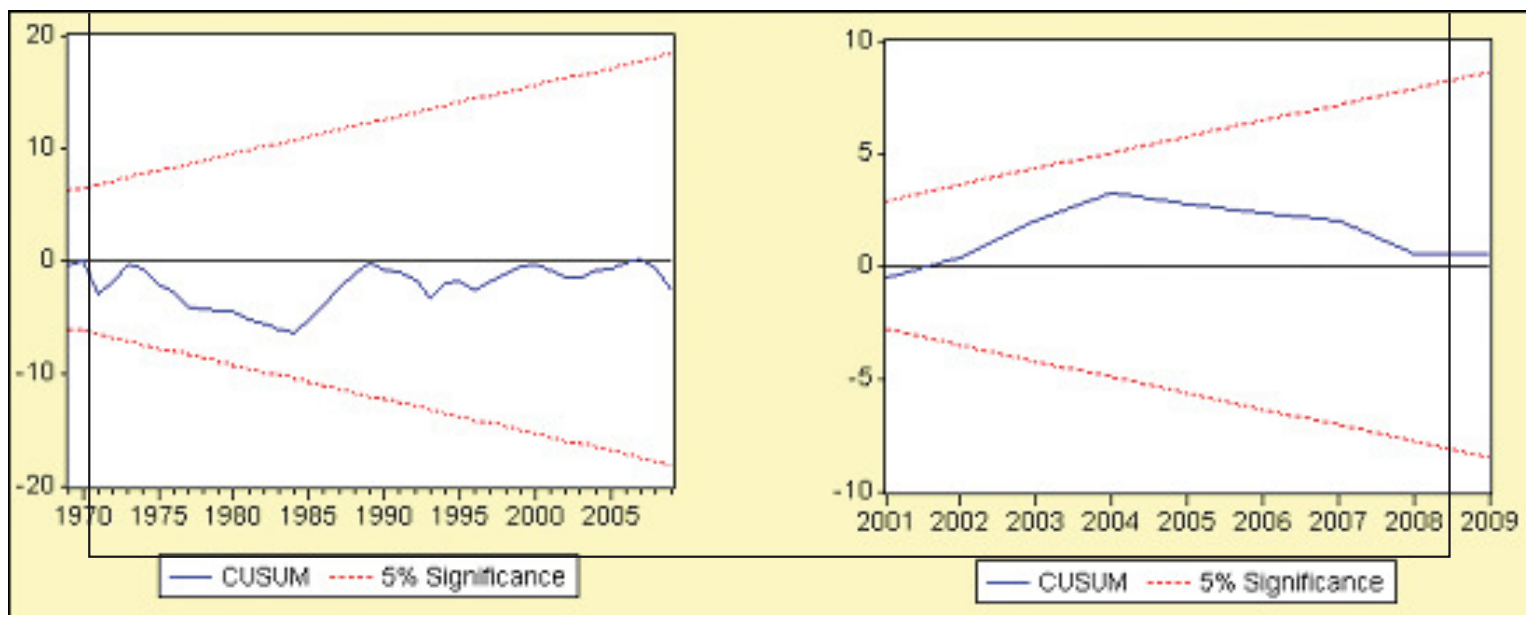

Source: Authors' calculations by using the econometric package EViews version 5 .

Figure 3 - Cusum Test for the United States

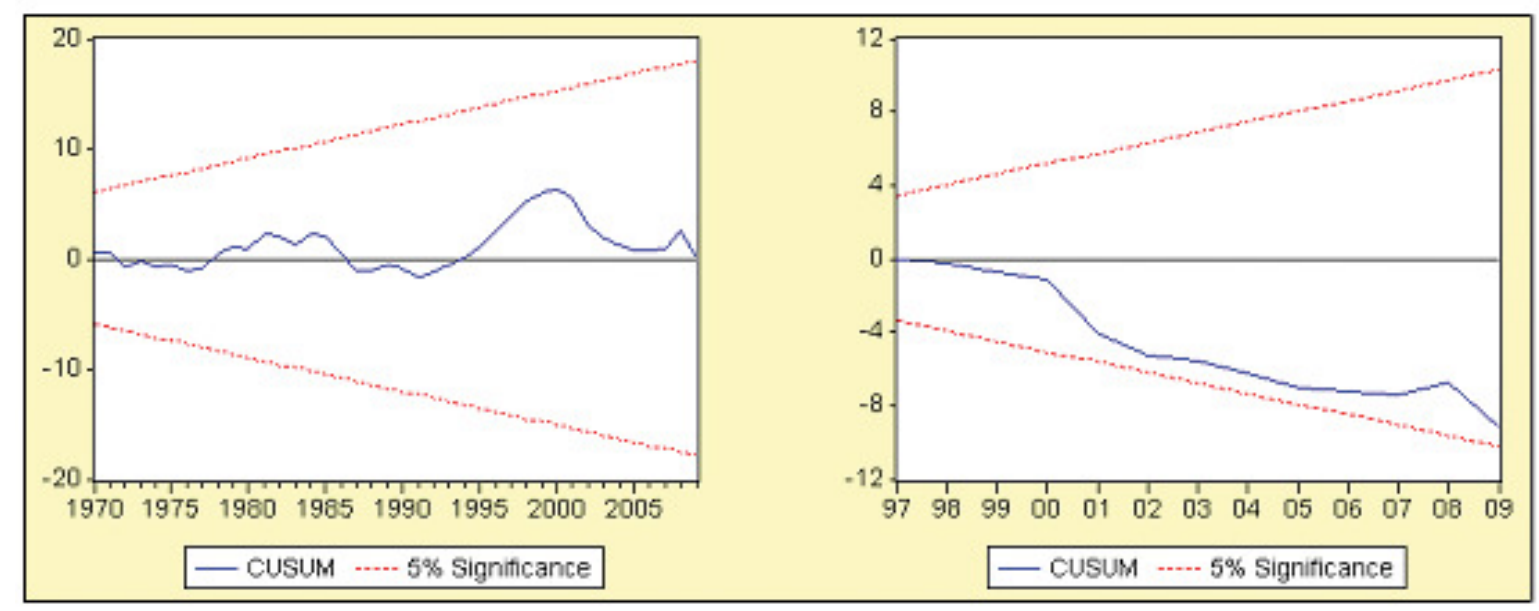

Source: Authors' calculations by using the econometric package EViews version 5 .

Recebido em: 21/05/2012

Aceito em: 05/06/2012 